PUBLIK: Jurnal Manajemen Sumber Daya Manusia, Administrasi dan Pelayanan Publik Sekolah Tinggi Ilmu Administrasi Bina Taruna Gorontalo Volume VI Nomor 2 Desember 2019

\title{
PENGELOLAAN BUDIDAYA RUMPUT LAUT DI DESA POPALO KECAMATAN ANGGREK KABUPATEN GORONTALO UTARA
}

\author{
Merlin I. Darise ${ }^{1}$ \& Usan Bagou ${ }^{2}$ \\ STIA Bina Taruna Gorontalo \\ bukujurnalstia@binataruna.ac.id ${ }^{1}$ \& bagousan11@gmail.com ${ }^{2}$
}

\begin{abstract}
ABSTRAK
Penelitian ini bertujuan untuk mengetahui pengelolaan budidaya rumput laut di Desa Popalo Kecamatan Anggrek Kabupaten Gorontalo Utara. Metode penelitian menggunakan jenis deskriptif pendekatan kualitatif. Teknik pengumpulan data dilakukan melalui wawancara mendalam kepada sejumlah informan, observasi dan pencatatan data sekunder yang berkaitan dengan permasalahan penelitian. Hasil penelitian menyimpulkan bahwa, perencanaan budidaya rumput laut di Desa Popalo Kecamatan Anggrek belum optimal. Hal ini terlihat dari proses pembudidayaan rumput laut yang dilakukan oleh petani yang bersifat sederhana tanpa ada pengamatan dan analisa sebelumnya dalam pemilihan bibit, pemilihan lokasi hingga metode penjualannya. Pelaksanaan budidaya rumput laut di Desa Popalo Kecamatan Anggrek belum optimal. Hal ini dikarenakan tidak adanya kegiatan perawatan dan pemeliharaan serta proses penanaman hingga proses panen dan kegiatan pasca panen masih dilakukan secara sederhana dan tanpa sarana dan prasarana yang memadai. Pengawasan budidaya rumput laut di Desa Popalo Kecamatan Anggrek belum optimal. Hal ini tampak dari jarangnya pemerintah dalam melakukan pemantau terhadap aktivitas budidaya rumput laut di Desa Popalo Kecamatan Anggrek. Disarankan, perlunya dilakukan budidaya rumput laut dengan melakukan persiapan dan perencanaan yang matang, dimulai dari pemilihan bibit, metode tanam, pemilihan lokasi, hingga tahap produksi. Perlunya dilakukan pelaksanaan budidaya rumput laut dengan melakukan perawatan dan pemeliharaan yang ditunjang dengan sarana dan prasarana yang memadai. Perlunya dilakukan pemantauan oleh pemerintah dalam hal ini Dinas Kelautan dan Perikanan Kabupaten Gorontalo Utara terhadap aktivitas budidaya rumput laut di Desa Popalo Kecamatan Anggrek.
\end{abstract}

Kata Kunci: Pengelolaan; Budidaya; Rumput; Laut

\section{PENDAHULUAN}

Indonesia merupakan negara maritim, kurang lebih 70 persen wilayah Indonesia terdiri dari laut yang pantainya kaya akan berbagai jenis sumber daya hayati dan lingkungan yang potensial (Dahuri, 2009;48). Potensi ini merupakan suatu sumber daya yang dapat dimanfaatkan untuk menuju Indonesia yang maju dan makmur. Wilayah pesisir menjadi 
PUBLIK: Jurnal Manajemen Sumber Daya Manusia, Administrasi dan Pelayanan Publik Sekolah Tinggi Ilmu Administrasi Bina Taruna Gorontalo Volume VI Nomor 2 Desember 2019

tumpuan dan harapan bagi pembangunan bangsa Indonesia di masa yang akan datang terutama komoditi perikanannya yang berlimpah

Untuk memaksimalkan pembangunan ekonomi dalam bidang kelautan dan perikanan maka pada tahun 2005 pemerintah mencanangkan suatu program Revitalisasi Pertanian Perikanan dan Kehutanan (RPPK) yang merupakan salah satu program nasional yang ditujukan untuk peningkatan kesejahteraan nelayan, peningkatan daya saing produk pertanian, perikanan dan kehutanan serta menjaga kelestarian sumberdaya pertanian, perikanan dan kehutanan.

Tingkat pertumbuhan ekonomi nasional ditentukan oleh pelaksanaan dan hasil-hasil pembangunan nasional serta kemampuan pemerintah dalam membangkitkan kegairahan dan partisipasi seluruh rakyat dalam melaksanakan pembangunan. Semakin tinggi pertumbuhan perekonomian, semakin besar pula sarana-sarana yang dapat disediakan untuk kepentingan masyarakat.

Sarana yang disediakan antara lain yaitu sarana pertanian, perikanan dan kehutanan yang dikembangkan untuk memberdayakan kehidupan masyarakat yang ada di pelosok desa. Pelaksanaan pembangunan yang dilakukan untuk meningkatkan swasembada pangan membutuhkan kerja keras dan kerja sama antara pemerintah dan masyarakat yang berhubungan dengan sektor-sektor tersebut. Kerja keras dalam arti bahwa semua sumber daya dan perhatian diarahkan pada program kerja guna meraih hasil yang diinginkan.

Budidaya rumput laut merupakan salah satu jenis budidaya dibidang perikanan yang mempunyai peluang untuk dikembangkan di perairan Indonesia. Rumput laut sendiri merupakan komoditas utama dari tiga program revitalisasi perikanan yang berperan penting dalam peningkatan kesejahteraraan masyarakat (Rismawati, 2012;60)

Rumput laut sebagai salah satu komoditas ekspor merupakan sumber devisa bagi Negara dan budidayanya merupakan sumber pendapatan nelayan, dapat menyerap tenaga kerja, serta mampu untuk memanfaatkan lahan perairan di kepulauan Indonesia yang sangat potensial sebagai Negara kepulauan maka pengembangan rumput laut indonesia dapat dilakukan secara luas oleh petani/nelayan. Dalam Peraturan Presiden Republik Indonesia Nomor 3 Tahun 2017 mengenai Rencana Aksi Percepatan Pembangunan Industri Perikanan Nasional, budidaya rumput laut termasuk dalam program prioritas.

Rumput laut atau alga (sea weed) merupakan salah satu komoditas penting perikanan di Indonesia. Produksi rumput laut Indonesia berasal dari pengambilan di laut dan pembudidayaan di laut. Disamping potensi lahan (daerah pasang surut) yang luas, kebutuhan rumput laut yang terus menunjukkan peningkatan merupakan prospek bagi pengembangan rumput laut. Indonesia 
PUBLIK: Jurnal Manajemen Sumber Daya Manusia, Administrasi dan Pelayanan Publik Sekolah Tinggi Ilmu Administrasi Bina Taruna Gorontalo Volume VI Nomor 2 Desember 2019

telah meningkatkan produksi rumpul laut dari 3.257.427 ton pada tahun 2016 menjadi 3.501 .583 ton pada tahun 2017 dan diperkirakan kenaikan 7,5\% (Neksidin, 2017).

Rumput laut telah menjadi salah satu sumber pendapatan bagi masyarakat Gorontalo khususnya di Kabupaten Gorontalo Utara saat ini. Rumput laut merupakan komoditi yang potensial dalam memberikan kontribusi pada pendapatan keluarga nelayan. Komoditi rumput laut ini telah dibudidayakan di Desa Popalo Kecamatan Anggrek Kabupaten Gorontalo Utara sejak tahun 2008. Pada awalnya terdapat 10 kelompok pembudidaya rumput laut namun yang tersisa saat ini hanya 1 kelompok saja dengan jumlah anggota sebanyak 10 orang.

Rumput laut merupakan salah satu sumber devisa negara, dan juga sumber pendapatan bagi masyarakat pesisir. Selain dapat digunakan langsung sebagai bahan makanan, beberapa hasil olahan rumput laut seperi agar-agar, carrageenan dan alginat merupakan senyawa yang penting bagi kesehatan tubuh maupun industri.

Budidaya rumput laut dilakukan masyarakat di Desa Popalo Kecamatan Anggrek Kabupaten Gorontalo Utara karena wilayah ini sangat cocok untuk budidaya rumput laut, sehingga usaha budidaya rumput laut menjadi salah satu kegiatan nelayan yang ada di Desa Popalo. Sebagai wilayah pesisir di Kabupaten Gorontalo Utara, Desa Popalomempunyai kondisi yang sangat memungkinkan untuk melakukan usaha budidaya rumput laut dengan persyaratan kondisi (iklim laut) pada kisaran yang normal termasuk kecepatan arus dan gelombang serta tinggi pasang surut dan konsentrasi kandungan unsur hara perairan yang normal sangat memungkinkan pengembangan usaha $\mathrm{i}$ ni terus dilakukan. Namun sangat disayangkan bahwa, besarnya potensi rumput laut yang ada di Desa Popalo tidak disertai dengan sistem pengelolaan yang baik, kurang matangnya perencanaan, pelaksanaan budi daya yang tidak totalitas hingga lemahnya pengawasan dari pihak pemerintah sehingga potensi tersebut belum mampu memberikan dampak yang lebih besar dalam hal ini kesejahteraan bagi nelayan.

Dari hasil pengamatan penulis, menunjukkan bahwa belum optimalnya pengelolaan budidaya rumput laut di Desa Popalo Kecamatan Anggrek Kabupaten Gorontalo Utara diakibatkan oleh kurang optimalnya persiapan atau perencanaan para nelayan dalam mengelola potensi rumput laut. Perencanaan merupakan suatu proses menentukan apa yang ingin dicapai di masa yang akan datang serta menetapkan tahapantahapan yang dibutuhkan untuk mencapainya. Kurang siapnya perencanaan para nelayan rumput laut akan berdampak pada lemahnya penanganan lingkungan yang berkaitan dengan kualitas perairan, pencemaran, serangan hama dan penyakit. Tahap selanjutnya adalah pelaksanaan, 
PUBLIK: Jurnal Manajemen Sumber Daya Manusia, Administrasi dan Pelayanan Publik Sekolah Tinggi Ilmu Administrasi Bina Taruna Gorontalo Volume VI Nomor 2 Desember 2019

dimana pelaksanaan sendiri merupakan tahap tindakan dari sebuah rencana yang sudah disusun secara matang dan terperinci. Pelaksanaan pembudidayaan rumput laut oleh para nelayan pun tidak lepas dari masalah seperti rendahnya teknik budidaya rumput laut yang sesuai dengan Standar Nasional Indonesia, dimana standar ini menetapkan kriteria dan persyaratan serta manajemen budidaya rumput laut di laut dengan memperhatikan (i) aspek keamanan pangan dan mutu (ii) kesehatan rumput laut (iii) aspek kelestariam lingkungan dan (iv) aspek sosial ekonomi. Akibatnya produksi nelayan rumput laut terbilang rendah yakni dalam masa panen sekitar 45 hari hanya menghasilkan $800 \mathrm{Kg}$ dengan harga jual sekitar 692.000. Kondisi tersebut berdampak pada tingkat kesejahteraan masyarakat nelayan rumput laut.

Selain itu, pengelolaan program budidaya rumput laut di Desa Popalo kurang mendapatkan pengawasan dari pihak Dinas Kelautan dan Perikanan Kabupaten Gorontalo Utara. Pengawasan merupakan upaya untuk memastikan antara perencanaan dan pelaksanaan berjalan sesuai dengan harapan. Pengawasan terhadap aktivitas budidaya rumupt laut di Desa Popalo masih lemah dalam hal pemilihan material serta teknik budidaya, meningkatkan pengolahan pasca panen, pemilihan bibit rumput laut berkualitas tinggi serta memperkuat kebijakan mengenai ketersediaan jaminan modal usaha melalui pengembangan sistem peminjaman modal dengan syarat yang mudah dan bunga yang ringan untuk pembudidaya.

Dari hal-hal tersebut di atas mengindikasikan bahwa belum optimalnya pengelolaan budidaya rumput laut yang dilihat dari aspek perencanaan, pelaksanaan, dan pengawasan belum dapat memperbaiki tingkat pendapatan masyarakat nelayan rumput laut di Desa Popalo Kecamatan Anggrek Kabupaten Gorontalo Utara.

Berdasarkan latar belakang di atas, penulis tertarik untuk melakukan penelitian secara mendalam dengan mengangkat judul "Pengelolaan Budidaya Rumput Laut di Desa Popalo Kecamatan Anggrek Kabupaten Gorontalo Utara"

\section{PERMASALAHAN}

Adapun rumusan masalah penelitian ini adalah Bagaimana pengelolaan budidaya rumput laut di Desa Popalo Kecamatan Anggrek Kabupaten Gorontalo Utara?

\section{TUJUAN DAN MANFAAT PENELITIAN}

\section{Tujuan Penelitian}

Berdasarkan rumusan masalah di atas, maka tujuan penelitian ini adalah untuk mengetahui pengelolaan budidaya rumput laut di Desa Popalo Kecamatan Anggrek Kabupaten Gorontalo Utara. 
Manfaat Penelitian

Adapun manfaat yang diharapkan dalam penelitian ini adalah sebagai berikut:

Secara teoritis diharapkan dapat mengembangkan ilmu pengetahuan khsusunya ilmu administrasi, dan juga dapat menjadi referensi bagi penelitian lainnya.

Secara praktis penelitian ini dapat menjadi acuan dan pertimbangan bagi Pemerintah Desa Popalo terutama dalam pengelolaan budidaya rumput laut.

\section{METODE PENELITIAN}

Jenis Penelitian penelitian yang digunakan adalah deskriptif dengan pendekatan kualitatif. Dan sumber daya berasal dari data primer dan sekunder. Teknik pengumpulan data dilakukan melalui observasi, wawancara, dan dokementasi. Sedangkan teknik analisis data dilakukan melalui reduksi data, penyajian data, dan verifikasi.

\section{Fokus Penelitian}

Fokus penelitian adalah apa yang akan menjadi titik perhatian suatu penelitian. Adapun fokus dalam penelitian ini yaitu:

\section{Perencanaan}

Merupakan kegiatan awal seperti penentuan lokasi, metode tanam hingga penyesuaian bibit dan penentuan kalender yang dilakukan oleh para nelayan rumput laut sebagai persiapan pengelolaan rumput laut

\section{Pelaksanaan}

Merupakan tahap utama seperti penanaman bibit dan perawatan dalam pengelolaan budidaya rumput laut yang ditunjang dengan teknik dan sarana budidaya rumput laut

\section{Pengawasan}

Merupakan tahap pengecekan yang dilakukan oleh Dinas Kelautan dan Perikanan Kabupaten Gorontalo Utara terkait dengan kondisi masyarakat para nelayan dalam membudidayakan rumput laut.

\section{HASIL PENELITIAN DAN PEMBAHASAN}

Rumput laut merupakan salah satu sumber devisa negara dan sumber pendapatan bagi masyarakat pesisir. Selain dapat digunakan langsung sebagai bahan makanan, beberapa hasil olahan rumput laut seperti agaragar, carrageenan dan alginat merupakan senyawa yang cukup penting dalam industri. Indonesia di samping mengekspor rumput laut, juga mengimpor hasilhasil olahannya yang dari tahun ke tahun semakin meningkat jumlahnya.

Sampai saat ini industri pengolahan di indoenesia yaitu agaragar masih secara tradisional dan semi industri. Termasuk pengelolaan rumput laut yang ada di Gorontalo Utara atau lebih tepatnya di Desa Popalo Kecamatan Anggrek.

Berikut uraian pembahasan terkait dengan pengelolaan budidaya rumput laut di Desa Popalo Kecamatan 
Anggrek Kabupaten Gorontalo Utara, dengan fokus penelitian; perencanaan, pelaksanaan, dan pengawasan.

Perencanaan yakni suatu cara yang memuaskan untuk membuat kegiatan dapat berjalan dengan baik, disertai dengan berbagai langkah yang antisipatif guna memperkecil kesenjangan yang terjadi sehingga kegiatan tersebut mencapai tujuan yang telah ditetapkan. Perencanaan ialah menyeleksi dan menghubungkan pengetahuan, fakta, imajinasi, dan asumsi untuk masa yang akan datang dengan tujuan memvisualisasi dan memformulasi hasil yang diinginkan, urutan kegiatan yang diperlukan, dan perilaku dalam batas-batas yang dapat diterima yang akan digunakan dalam penyelesaian. Perencanaan adalah suatu cara untuk mengantisipasi dan menyeimbangkan perubahan.

Adapun perencanaan yang dimaksudkan dalam penelitian ini adalah merupakan kegiatan awal seperti penentuan lokasi, metode tanam hingga penyesuaian bibit dan penentuan kalender hingga ke tahap penjualan yang dilakukan oleh para nelayan rumput laut sebagai persiapan pengelolaan rumput laut. Hasil penelitian dan analisis penulis, dapat diketahui bahwa perencanaan budidaya rumput laut oleh petani rumput laut di Desa Popalo Kecamatan Anggrek belum optimal. Hal ini terlihat dari proses pembudidayaan rumput laut yang dilakukan oleh petani yang bersifat sederhana tanpa ada pengamatan dan analisa sebelumnya dalam pemilihan bibit, pemilihan lokasi hingga metode penjualannya.

Pelaksanaan adalah suatu tindakan atau pelaksanaan dari sebuah rencana yang sudah disusun secara matang dan terperinci, implementasi biasanya dilakukan setelah perencanaan sudah dianggap siap. Secara sederhana pelaksanaan bisa diartikan penerapan. Kata pelaksanaan bermuara pada aktivitas, adanya aksi, tindakan, atau mekanisme suatu sistem. Ungkapan mekanisme mengandung arti bahwa pelaksanaan bukan sekedar aktivitas, tetapi suatu kegiatan yang terencana dan dilakukan secara sungguh-sungguh berdasarkan norma tertentu untuk mencapai tujuan kegiatan.

Sementara itu, pelaksanaan yang dimaksudkan dalam penelitian ini adalah tahap utama seperti penanaman bibit dan perawatan dalam pengelolaan budidaya rumput laut yang ditunjang dengan teknik dan sarana budidaya rumput laut. Hasil penelitian dan analisis penulis, dapat diketahui bahwa pelaksanaan budidaya rumput laut petani rumput laut di Desa Popalo Kecamatan Anggrek belum optimal. Hal ini dikarenakan tidak adanya kegiatan perawatan dan pemeliharaan serta proses penanaman hingga proses panen dan kegiatan pasca panen masih dilakukan secara sederhana dan tanpa sarana dan prasarana yang memadai.

Sistem Pengawasan adalah segenap kegiatan untuk meyakinkan dan menjamin bahwa tugas/pekerjaan telah dilakukan sesuai dengan rencana yang telah ditetapkan. Pengawasan 
PUBLIK: Jurnal Manajemen Sumber Daya Manusia, Administrasi dan Pelayanan Publik Sekolah Tinggi Ilmu Administrasi Bina Taruna Gorontalo Volume VI Nomor 2 Desember 2019

dapat di definiskan sebagai proses untuk menjamin bahwa tujuan-tujuan organisasi dan manajemen dapat tercapai. Ini berkenaan dengan caracara membuat kegiatan-kegiatan sesuai yang direncanakan. Pengertian ini menunjukkan adanya hubungan yang sangat erat antara perencanaan dan pengawasan.

Kontrol atau pegawasan adalah fungsi di dalam manajemen fungsional yang harus dilaksanakan oleh setiap pimpinan semua unit/satuan kerja terhadap pelaksanaan pekerjaan atau pegawai yang melaksanakan sesuai dengan tugas pokoknya masingmasing. Dengan demikian, pengawasan oleh pimpinan khusunya yang berupa pengawasan melekat (built in control), merupakan kegiatan manajerial yang dilakukan dengan maksud agar tidak terjadi penyimpangan dalam melaksanakan pekerjaan. Suatu penyimpangan atau kesalahan terjadi atau tidak selama dalam pelaksanaan pekerjaan tergantung pada tingkat kemampuan dan keterampilan pegawai.

Adapun pengawasan yang dimaksudkan dalam penelitian ini adalah tahap pengecekan yang dilakukan oleh Dinas Kelautan dan Perikanan Kabupaten Gorontalo Utara terkait dengan kondisi masyarakat para nelayan dalam membudidayakan rumput aut. Hasil penelitian dan analisis penulis, dapat diketahui bahwa pelaksanaan budidaya rumput laut di Desa Popalo Kecamatan Anggrek belum optimal. Hal ini dikarenakan tidak adanya kegiatan perawatan dan pemeliharaan serta proses penanaman hingga proses panen dan kegiatan pasca panen masih dilakukan secara sederhana dan tanpa sarana dan prasarana yang memadai.

Secara keseluruhan bahwa pengelolaan budidaya rumput laut di Desa Popalo Kecamatan Anggrek Kabupaten Gorontalo belum optimal. Hal ini terlihat dari sistem perencanaan, pelaksanaan hingga pengawasan yang belum dilakukan secara maksimal.

\section{SIMPULAN}

Berdasarkan hasil penelitian dan pembahasan yang telah dipaparkan sebelumnya, dapat disimpulkan hal-hal sebagai berikut:

1. Perencanaan budidaya rumput laut di Desa Popalo Kecamatan Anggrek belum optimal. Hal ini terlihat dari proses pembudidayaan rumput laut yang dilakukan oleh petani yang bersifat sederhana tanpa ada analisa sebelumnya dalam pemilihan bibit, pemilihan lokasi hingga metode penjualannya.

2. Pelaksanaan budidaya rumput laut di Desa Popalo Kecamatan Anggrek belum optimal. Hal ini dikarenakan tidak adanya kegiatan perawatan dan pemeliharaan serta proses penanaman hingga proses panen dan kegiatan pasca panen masih dilakukan secara sederhana dan tanpa sarana dan prasarana yang memadai.

3. Pengawasan budidaya rumput laut di Desa Popalo Kecamatan Anggrek belum efektif. Hal ini 
PUBLIK: Jurnal Manajemen Sumber Daya Manusia, Administrasi dan Pelayanan Publik Sekolah Tinggi Ilmu Administrasi Bina Taruna Gorontalo Volume VI Nomor 2 Desember 2019

tampak dari kurangnya pemerintah dalam melakukan pemantau terhadap aktivitas budidaya rumput laut di Desa Popalo Kecamatan Anggrek.

4. Secara keseluruhan dapat disimpulkan bahwa pengelolaan budidaya rumput laut di Desa Popalo Kecamatan Anggrek Kabupaten Gorontalo belum optimal. Hal ini terlihat dari perencanaan, pelaksanaan hingga pengawasan yang belum dilakukan secara maksimal.

\section{SARAN}

Berdasarkan hasil penelitian dan kesimpulan di atas, maka berikut saran yang penulis tawarkan sebagai bahan pertimbangan;

1. Perlunya dilakukan budidaya rumput laut dengan melakukan persiapan dan perencanaan yang matang, dimulai dari pemilihan bibit, metode tanam, pemilihan lokasi, hingga tahap produksi

2. Perlunya dilakukan pelaksanaan budidaya rumput laut dengan melakukan perawatan dan pemeliharaan yang ditunjang dengan sarana dan prasarana yang memadai.

3. Perlunya dilakukan pemantauan oleh pemerintah dalam hal ini Dinas Kelautan dan Perikanan Kabupaten Gorontalo Utara terhadap aktivitas budidaya rumput laut di Desa Popalo Kecamatan Anggrek.

4. Perlunya dilakukan pengelolaan budidaya rumput laut yang lebih serius dalam rangka meningkatkan kesejahteraan para petani rumput laut dengan mengoptimalkan perencanaan, pelaksanaan dan pengawasan.

\section{DAFTAR PUSTAKA}

Abdul Wahab, Solichin. 2008. Analisis Kebijaksaan dari formulasi ke implementasi kebijaksanaan negara. Jakarta: Bumi Aksara.

Abidin, I. 2004. Kebijakan Publik, Teori dan Praktek. Yogyakarta: Penerbit Andi.

Albrow. 2010. Birokrasi. Cetakan Ketiga. Yogyakarta: Tiara Wacana.

Arikunto, Suharsimi. 2009. Manajemen Pendidikan. Yogyakarta: Aditya Media

Danim, Sudarwan. 2011. Pengantar Studi Penelitian Kebijakan. Jakarta: Bumi Aksara

Dimock \& Fox, 2007. Administrasi Negara Jilid 1 dan 2. Jakarta: Rieneka Cipta.

Dunn, W. N. 2009. Public Policy Analysis: An Introduction. Englewood Cliffs, N. J: Prentice Hall.

Gie, The Liang 2010. Administrasi Perkantoran. Yokyakarta: Modern Liberty

Guntur Setiawan, 2010. Implementasi Dalam Birokrasi Pembangunan. Bandung: Remaja Rosdakarya offset. 
PUBLIK: Jurnal Manajemen Sumber Daya Manusia, Administrasi dan Pelayanan Publik Sekolah Tinggi Ilmu Administrasi Bina Taruna Gorontalo Volume VI Nomor 2 Desember 2019

Hasan Shadily. 2007. Kamus Besar Bahasa Indonesia. Jakarta: Balai Pustaka.

Ibrahim, Amin. 2008. Teori dan Konsep Pelayanan Publik Serta Implementasinya. Bandung: Mandar Maju.

Ismani, 2009. Debirokrasi dan Deregulasi. Jakarta: Obor.

LAN. 2008. Standar Pelayanan Publik. Jakarta: Lembaga Administrasi Negara.

Kadarwati. 2008. Administrasi Negara Pembangunan. Jakarta: Karunia LP3ES.

Keban, Jeremias T. 2008. Enam Dimensi Strategi Administrasi Publik, Konsep, Teori dan Isu. Yogyakarta: Gava Media.

Kurniawan, Luthfi J. Mokhamad Najih. 2008. Paradigma Kebijakan Pelayanan Publik. Malang: Trans Publishing

Kusdi. 2009. Transformasi Pelayanan Publik. Yogyakarta: Pembaruan.

Marzuki. 2012. Metodologi Riset, Yogyakarta: Ekonisia

Moleong, Jexy J., 2007. Metodologi Penelitian Kualitatif. Bandung: Rosda.

Nurdin Usman. 2009. Konteks Implementasi Berbasis

Kurikulum. Jakarta: PT. Raja Grafindo Persada.

Pasolong, Harbani. 2011. Teori Administrasi Publik. Bandung: Alfabeta.

Rosenbloom, David H. 2008. Public Administration; understanding Management, Politics, and Law in the Public Sector. $6^{\text {th }}$ edition.
New York: Mc Graw Hill International Edition.

Santoso, Pandji. 2008. "Administrasi Publik, Teori dan Aplikasi Good Governance”, Cet. Pertama. Bandung: PT.Refika Aditama

Santoso. 2009. Birokrasi Terhadap Peningkatan Pelayanan Publik Di Era Otonomi. Bandung: PT. Refika Aditama.

Sri Yuliani, 2009. Pengantar Ilmu Administrasi Negara, FISIP Universitas Sebelas Maret, Surakarta.

Sugiyono. 2013. Prosedur Penelitian: Suatu Pendekatan Praktek. Jakarta: PT. Rineka Cipta.

Sulistiyani Ambar Teguh. 2011. Manajemen dan Sumber Daya Manusia: Konsep Teori dan. Pengembangan Dalam Konteks Organisasi Publik. Yogyakarta: Graha Ilmu.

Tangkilisan, Hersel Nogi S. 2008. Kebijakan Publik yang Membumi. Yogyakarta: YPAPI dan Lukman Offset.

Ulbert, Silalahi. 2011. Pengantar Ilmu Administrasi. Bandung: Sinar Baru.

Wibawa, S. 2007. Kebijakan Publik. Jakarta: Intermedia.

Winarno, Budi. 2007. Kebijakan Publik: Teori dan Proses. Yogyakarta: Media Pressindo.

\section{Dokumen Lain;}

UUD 1945 Negara Kesatuan Republik Indonesia

Keputusan President No. 22 tahun 1982 tentang Pengembangan 
PUBLIK: Jurnal Manajemen Sumber Daya Manusia, Administrasi dan Pelayanan Publik Sekolah Tinggi Ilmu Administrasi Bina Taruna Gorontalo

Volume VI Nomor 2 Desember 2019

Budidaya Laut di Perairan

Indonesia. 